\title{
Development of student work sheet based on contextual approach to trigonometry material
}

\author{
Hermanto ${ }^{1}$, Irwan ${ }^{2}$, Ridwan ${ }^{3}$ \\ ${ }^{123}$ Universitas Negeri Padang, Padang - Indonesia, (hermanto171288@gmail.com)
}

\begin{abstract}
Using Mathematics Student Worksheet (LKS) made by math teachers are not optimal, especially in helping students connect learning in life. Therefore, it is necessary to develop LKS that can provide opportunities for students to construct their knowledge, so that students can find their own learning concept. Trigonometry material is an important material in learning mathematics and relevance with other lessons. In this research, developed LKS with contextual learning approaches for trigonometric materials. The aim of this development is to produce mathematics LKS based on contextual approach which is valid, practical and effective. The subjects of the study were 29 students. Validation are done by the expert ie lecturer of mathematics education, education technology, and language. The practicality of LKS has been seen from the observation of the implementation of learning, practicality of questionnaires, interviews conducted with students and teachers. Effectiveness has been seen from the results of student learning outcomes.
\end{abstract}

Keywords: student's worksheet, contextual, plomp model.

\section{Introduction}

Education is a lifelong human need. Education is very important, because without human education will be difficult to develop and even will be backward. Education is an effort to improve the quality of human resources both physical, mental and spiritual. The advance of a country can be seen from the level of science owned by the citizen. One science closely related to the progress of the nation and the improvement of human resources is mathematics.

Mathematics is one branch of science that plays an important role in the development of science and technology that is as a tool, mindset formers, and formers attitude. The important role of mathematics recognized Cockcroft (in Sadiq: 2007) that life in the 20th Century would have been difficult if without mathematics. That is why subjects of mathematics taught from basic education to higher education [1]. Mathematics is a discipline that is taught in every level of education, of course, learning has a goal to be achieved. Given the importance of mathematics in life, it is necessary effort in improving the quality of mathematics education at every level of education in Indonesia. For that need to be made learning oriented to active learning, creative, effective and fun that will lead to improving the quality of student learning. 
The mathematics learning that has been applied so far in schools has not been satisfactory in general, as there are still many students earning grades below.Therefore, teachers should look for alternatives to using new learning methods and approaches that can improve students learning outcomes.One of the possible learning alternatives to improve students learning outcomes is to use a contextual learning approach. The contextual learning approach according to Depdiknas is a learning concept that helps teachers connect between the material taught to the real-world situations of the students and encourages students to make connections between their knowledge and their application in daily life by involving seven effective learning components that are contracting, asking, community learning, modeling, ref-selection, and true assessment.According to Masnur (2008: 41), contextual learning is a concept of learning that helps teachers connect learning materials with students' real-world situations, and encourages students to make connections between their knowledge and application in their daily lives [2]. Thus students is requiring to truly understand the situations they face and what they learn in learning mathematics.

In order for the learning process to run maximally, then there should be teaching materials that can support the student is the Student Worksheet (LKS). LKS is a learning tool that is a complement or a means of supporting the implementation of learning that can contain material or steps to complete the task.LKS can also be used to facilitate teachers in delivering materials and also can save time in teaching, because with the teaching materials such as LKS students can already see, understand, and work on the problems in the LKS and can directly answer it on the LKS. According toPrayitno (2003:7) "LKS is a means to convey the concept to students either individually or in small groups that contain instructions for conducting various activities" [3].Meanwhile, according to Trianto (2009: 222) describes that "LKS is a student guide that is used to conduct investigation or problem solving activities" [4].

The use of LKS according to Prastowo (2012: 205) is a teaching material that can minimize the role of educators, as teaching materials that make it easier for students to understand the material given, as a compact and rich teaching materials to practice, and facilitate the implementation of teaching to students.LKS developed is linking between material and questions directly related to the student's real life and LKS designed with a more attractive appearance.So that the researcher wish to develop RPP and LKS the based approach of contextual learning which is expected to optimize students' mathematical reasoning ability.

\section{Method}

This type of research is development research.According to Seels and Richey (alimSumarmo; 2010) development means the process of translating or describing the design specifications into physical features [5]. This study uses a development model according to Plomp [6], which consists of three phases, namely preliminary research, prototyping stage, and assessment stage.

The preliminary research phase consists of needs analysis, curriculum analysis, concept analysis and student analysis. In the prototyping stage, the prototype is formative evaluation. Phase of development or prototype (prototyping stage) consists of prototype 1, namely self-evaluation and expert review; prototype 2 is one to one; prototype 3 is small group; prototype 4 , that is field test. In the assessment phase, field test is conducted in class X.2 SMA Kartika I-5 Padang to see the practicality and effectivenes. Research data were collected through self-evaluation sheets, validation sheets, observation sheets and interview guides, teacher and student response sheets, and final test of learning outcomes. Validation of the device has done by three lecturers of Mathematics, one lecturer of Indonesian language, and one lecturer of Educational Technology. 


\section{Results and Discussion}

\section{Preliminary Research}

The purpose of this phase is to define and define the requirements required for the development of LKS.This stage has done by analyzing the objectives within the boundaries of the developed subject matter.On requirement analysis is done Information gathering is done by interviewing and observing the implementation of mathematics learning in the classroom, as well as giving questionnaire about student's LKS needs.From the questionnaire given to the students can be obtained information that $100 \%$ of students feel helped by the use of LKS to understand the subject matter.From the questionnaire Lecturers to understand the subject matter.As many as $57.9 \%$ of students said the effective paper size used is A4 size (quarto), because students feel A4 paper size makes it easier for students to bring and insert the LKS into the bag.While $52.6 \%$ of students prefer color with the dominant color of blue color, and as many as $100 \%$ of students feel need additional interesting animated drawing on LKS to increase student attractiveness in learning. While the results of interviews with teachers indicate the needs of students in the form of new learning approaches in addition to conventional learning commonly used in schools.The results of these interviews expect an approach that allows students to be more active in learning and make students feel mathematics can not be far from the daily life of students.Based on this interview, the researcher also get information that trigonometric learning material is quite difficult to understand the students, this is because this material requires analysis and strong understanding.

2. Results of Phase Prototyping

a. LKS design

Preliminary Research results serve as the basis for the development or manufacture of prototypes. Once the indicators are formulated, as well as concept maps are established then the next step is to design learning tools in the form of LKS.Characteristics of LKS based on this contextual learning approach has a paper size of $29.7 \mathrm{~cm} \times 21 \mathrm{~cm}$ or A4 size (quarto).The type of writing used in this LKS is Comic Sains Ms. Presentation of the material begins by giving problems in everyday life and provide definitions and examples related to the material being studied.Students are required to construct the knowledge gained to discover new knowledge based on the illustration of their daily life.To further enhance cooperation and discussion, LKS based on this contextual learning approach also provides group-resolved questions and the results of the class discussion are presented to the class so that other groups can respond. In addition to group exercises, LKS also presents the exercises for individuals.It aims to make the reviewers more accurate, as they can see students' individual understanding results and provide more authentic judgments and there is also a place to give each student individually.

The main background color used in the contextual approach is blue.LKS cover design based on contextual learning approach can be seen in Figure 19. In general, LKS based on contextual learning approach using A4 paper (size 29,7 cm $\times 21 \mathrm{~cm}$ ). Type of writing used in this LKS for the title at each meeting that is Broadway with the size of 16 letters, the letters in the guidance of the use of LKS is Ar-Blanca with 12 letter size, write letters (script) is Comic Sans MS with 12 letter size.The part of the title and the part that needs to get the emphasis is given a more attractive color. LKS has been designed with the dominant color is the blue color.

LKS uses standard language according to Enhanced Spelling (EYD). LKS uses simple language and communicative and in accordance with the level of understanding of high school students so that the presentation of the material on the LKS can be understood students well. The questions in the LKS are arranged with clear sentences so as to lead the students to get the expected answers.

b. Prototype one

Prototype 1 is an early stage of the design of learning tools. To obtain a valid device, there are two steps done in validating the learning device, which is self evaluation and expert 
review.Below is described the prototype validation results of instructional devices that have been designed.

1) Self Evaluation Results

Self evaluation is correcting small mistakes against yourself. Before consulting and discussing to the experts, the first self-evaluation of the learning device that has been designed.Aspects seen in the RPP is a typing error and punctuation accuracy. Mistakes mostly occur in the initial typing of words that should be capitalized and punctuation such as placement of a comma, and a dot. In addition, errors are also seen in sentence writing.After reading many times, there are still some sentences that are less precise and difficult to understand.Aspects has seen in the LKS are typing errors, punctuation accuracy, text size accuracy, precision of image placement and availability of empty spaces to solve the problem adequately.Mistakes occur in typing of words and punctuation, use of co-sign and command (exclamation mark or question mark).In addition, errors are also visible on the precise size of the image placement and the exact blank to solve the problem is too little.

2) Validation Results

Learning Tool is discussed first with supervisor, then validated to experts consisting of 5 people validator.Lecturers who become vali-datorcomes from 3 areas of expertise that is mathematics, education technology and language.In the LKS validation results showed that for the didactic aspect obtained the average validity of 3.13 with valid categories, the content aspect with the average validity of 3.67 with the category is very valid, the language aspect with an average of 4.00 with the category is very valid, and aspect of 3,00 graduation with very valid category.Overall LKS validity is 3.45 with very valid category. Thus it can be concluded that LKS based approach to contextual learning has been valid.

c. Prototype two

One-to-one evaluation is done by asking students to comment on the designed LKS. LKS is given to students of grade X.2 SMA Kartika I-5 Padang with moderate ability and low ability of 1 person.Students required to work on LKS according to their ability.The three students have not studied the material related to the LKS that will be given as much as 6 LKS.Activities undertaken are observing and recording responses, suggestions, and student questions about LKS. In addition, filling in an observation sheet containing such things as the elusive part of the clues, problematic sentences presented elusive, and questions that students do not understand in the LKS.

Overall students interested in the presentation of material on the LKS. The material presented clearly and easily understood through various activities contained in the LKS. So students motivated to perform activities that exist on the LKS and answer the questions given. During the interview the teacher also observed the activities during one to one. Based on the results of interview analysis and obser-vasi then be revised.

d. Prototype Three

After a person-to-person evaluation, a small group evaluation was done by practicing learning tools that had been designed in a group of 8 students. Students consisting of 8 people divided into 2 groups per group consisting of 4 people with high ability 1 person, while 2 people and low 1 person. This small group evaluation conducted on students of class X.2. A small group evaluation conducted during 6 meetings on Trigonometry material.

At this stage the observation is done when the implementation of small group takes place. The results of observation there are several revisions of the learning tool that is the improvement of the question sentence, the time of execution of the exercise and the presentation activities. Based on these observations, a revision is made.

e. Field Test Test Results in SMA Kartika I-5 Padang

At the assessment stage (stage stage) is a prototype stage 4, conducted field tests in class X.1 SMA Kartika I-5 Padang to see the practicality and effectiveness of learning tools based 
on contextual learning approach. Trial conducted as many as 6 times that is on trigonometric material. Here are the results of field trials in class X.1.

The result of practice test by using questionnaire of teacher response gives practical value $86,7 \%$. Based on the criteria that have been made, the practicality of instructional tools on teacher responses based on contextual learning approach is very practical. Seen from the filled questionnaire, according to the LKS teacher based on scientific approach can be easy to use, interesting, well understood, can motivate students to learn math and understand the concept well critically in investigating the problem.

The result of questionnaire of students responses that the level of practicality for the aspect of ease of use $77.01 \%$ with practical calculation, time efficiency aspect $74.14 \%$ with quite practical category, $75.57 \%$ attractiveness aspect with practical category, $06 \%$ with practical accountability and benefits aspects of LKS $76.21 \%$ with practical category. The average level of practicality of the three aspects of LKS practicality based on contextual learning approach according to the students responses is $75.20 \%$. Thus, it can be conclude that the LKS-based approach to contextual learning is practical according to students responses.

3) Assessment Stage

Learning outcomes obtained are used to see the effectiveness of instructional tools in terms of students learning evaluations during the use of this lesson. This test is given by giving 4 questions that each have a score. Students who take this test as many as 29 students. Based on the results of the tests conducted, there are 18 students or $62.07 \%$ complete means the value of students above the determined KKM score and 7 students or $37.93 \%$ is not yet complete means the value of students is still below the KKM. Furthermore, from the average of the learning class using learning apparatus based on contextual learning approach that is 71,80 means that it has been shown in class.

\section{Conclusions}

This research is a development research that produces LKS based on contextual learning approach which is valid, practical and effective. to improve student learning outcomes SMA Kartika I-5 Padang Class X. Based on this conclusion the researcher suggests to be able to develop LKS based on contextual learning approaches on other materials and can be used as a guide for teachers in implementing learning.

\section{Acknowledgments}

The author would like to thank Dr.H. Irwan, M.Si and Dr. Ridwan, M.Sc. Ed as a lecturer and lecturers and graduate lecturers of Padang State University who have provided guidance and guidance sincerely and patiently in the completion of this article. This article is based on a thesis written by Hermanto entitled "Development of Learning-Based Learning Approach Contextual Approach to Increase Mathematical Reasoning Competitiveness of High School Students of Grade X Second Grade".

\section{References}

Shadiq, F. (2007). Laporan Hasil Seminar dan Lokakarya Pembelajaran Matematika 15-16 Maret 2007 di P4TK Matematika. Yogyakarta: Depdiknas, P4TK Matematika Yogyakarta.

Masnur, Muslich. 2008. KTSP Pembelajaran Berbasis Kompetensi dan Kontekstual. Jakarta: PT Bumi Aksara.

Prayitno, Edi. (2003). Materi Diklat Pedoman Pengembangan System Penilaian. Yogyakarta: FMIPA UNY. 
Trianto. (2009). Mendesain Model Pembelajaran Inovatif-Progesif. Jakarta: Kencana Prenada Media Kelompok.

Sumarmo. (2010). Berfikir dan Disposisi Matematika: Apa, mengapa, dan Bagaimana Dikembangkan Pada Peserta didik. [Online]. Tersedia pada http://Math.sps.upi.edu/wp content/uploads/2010/2. [diakses tang-gal 27 Juli 2015].

Plomp, T dan N. Nieveen. (2013). Educational Design Research. Enshede: Netherlands Institute for Curriculum Development (SLO). 